Pract. oto-rhino-laryng. 1963;25:127

\title{
Peripharyngeal Swellings
}

G.A.

Sedee

\section{Utrecht}

Author's address : Dr. G. A. Sedee, Universiteitskliniek voor Keel-, Neus-, en Oorziekten, Utrecht (Netherlands)

Swellings in the neck sometimes offer difficulties in diagnosis. The writer gives a scheme for determining possible affections. One can differentiate the course of propagation on the basis of anatomical data or the site of the first protrusion. The possible diagnosis leads to the intended treatment. In the case of surgery this means a broad operation field with control of the large vessels.

In the case where a biopsy must be taken

it must be possible to let the definite operation follow straightaway. 